石油技術協会誌 第 55 巻 第 3 号（平成 2 年 5 月）

JOURNAL OF THE JAPANESE ASSOCIATION FOR PETROLEUM TECHNOLOGY

VOL. 55 , NO. 3 (May, 1990)

\title{
炭酸塩岩有機炭素の迅速測定法
}

\author{
山田 畺*.町原勉*
}

(平成 2 年 1 月 25 日受付, 2 年 3 月 19 日受理)

\section{Rapid Determination of Organic Carbon in Carbonate Rocks}

By

Makoto YAMADA and Tsutomu MACHIHARA

\begin{abstract}
A rapid method for determination of organic carbon in carbonate rocks has been developed to replace the normal procedure in which carbonate samples are pretreated with hydrochloric acid to decompose carbonate minerals. The method involves dry combustion of organic material in an oxygen stream and subsequent measuring of carbon dioxide $\left(\mathrm{CO}_{2}\right)$ generated.

Experimental data were obtained by changing combustion temperatures $\left(450-900^{\circ} \mathrm{C}\right)$ and combustion time (5-15 minutes) using YANACO CHN-corder (model MT-5). Based on the difference of the decomposition rates between organic matter (coal and shale) and inorganic carbonates (calcium carbonate and dolomite), we have concluded that combustion conditions of $550{ }^{\circ} \mathrm{C}$ for 15 minutes are appropriate for organic-carbon analysis of carbonate rocks. Amounts of sample needed for experiments are $10-100 \mathrm{mg}$. More than $90 \%$ of the organic carbon can be detected directly under these conditions without any pretreatment of the sample, and the influence of inorganic carbon is less than $0.03 \%$ of the sample weight. This simplified method is also applicable for organic-carbon analysis of non-calcareous samples such as shales.
\end{abstract}

\section{1.はじめに}

根源岩中に含まれる有機物の量の指標である全有機炭 素量（TOC）は，有機物のタイプ，熟成度と並び，根 源岩の石油生成ポテンシャルを評価するための基本的 かつ重要なパラメーターである。しかし，炭酸塩岩は 泥質岩に比較するとその全有機炭素量がかなり小さい （HUNT, 1961，1972）ため, その根源岩ポテンシャル は，泥質岩の評価基準から判断すると低いとされてきた。 田口（1982a，b）は炭酸塩岩有機物の特質を泥質岩之 比較し, 炭酸塭岩では有機物量が少なくても, 石油根源 岩としての能力は十分にあると論じている。しかしなが

* 石油公団石油開発技術センター

Copyright (C) 1990, JAPT
ら，最近に至るまで炭酸塭岩中の有機物に関する研究は， 泥質岩と比較してきわめて少ない。 その理由のひとつとして，炭酸塭岩中に大量に含まれ る炭酸塩鉱物の影響により泥質岩と同様の分析手法を適 用することが困難である点が挙げられる。すなわち，炭 酸塩岩は泥質岩に比べていともと岩石中に存在する有機 物の量が少ないことに加えて，炭酸塩鉱物（無機炭素） が多量に存在しているため, 泥質岩と比較して大量の試 料が必要となるほか，炭酸塩鉱物を除去するための塩酸 处理操作が煩雑となるうえに時間も要し，そのため詋差 あ入りやすくなるからである。また，酸处理が有機物に 対して与える影響も無視できない（佐藤他，1972）。 そのため全有機炭素量を簡便に分析する手法がいく つか提案されてきた（DEAN，1974，HEISTAND and HUMPHRIES, 1976, KROM and BERNER, 1983, 松 
林他，1977，鈴木他，1986）。そ机によると比較的低温 度での燃焼方法が泥質岩試料の有機炭素の分析に適用で きる可能性が示された。

本研究では, 炭酸塩岩試料について迅速加つ簡便にそ の全有機炭素量が測定できる分析条件の確立を目的とし て, 炭酸塩鉱物の温度に対する安定性と有機物の燃焼率 を詳細に検討したので，その結果を報告する。

\section{2. 低温然焼法の研究経緯}

全有機炭素量を簡便に测定する試みとして，DEAN （1974）は湖底堆積物 50 試料を $550^{\circ} \mathrm{C}, 1$ 時間加熱した之 きの重量隇少を有機炭素量とし, 実際に CHN 分析装置 (HEWLETT PACKARD 社製) で測定した有機炭素 量とよく相関すると報告している。しかしながら，分析 した湖底堆積物試料は有機炭素量が $3 \sim 30 \%$ 之高く, 有 機炭素量の小さい試料 $(<0.5 \%)$ に対しては検討されて いない。

KROM and BERNER (1983) は, 試料を低温 (450 $\sim 500^{\circ} \mathrm{C}$ ) で長時間（16 時間）加熱することにより， 炭酸塩鉱物を分解せずに有機炭素量が測定できること を報告している。この方法では，まず，炭素分析計 (LECO CR-12)を用いて, 試料の全炭素量 (有機炭素 量十無機炭素量）を測定し，つづいて上述した低温，長 時間の加熱を行い有機物を除去した試料の炭素量（無機 炭素）を測定する。そして全炭素量から無機炭素量を差 し引いた值を有機炭素量とするものである。ただし，彼 らの論文にも述べられているょうに，無機炭素量が有機 炭菜量の 20 倍以上ある試料には応用が難しいという久点 がある。HUNT（1961）によれば，石灰岩扰よび苦灰岩 400 試料の平均有機炭素量は $0.29 \%$ である。例えば無機 炭素を $10 \%$ 含有する試料では有機炭素量が $0.5 \%$ 以上必 要とされるため，実際の炭酸塩岩試料に応用することは 不適当と考えられる。

HEISTON and HUMPHRIES (1976) はオイルシェー ル中の有機炭素が $450^{\circ} \mathrm{C} \pm 10^{\circ} \mathrm{C}, 5$ 分の然焼条件で簡便 に測定できるとしている。この方法はDEAN (1974) お よび KROM and BERNER (1983) の方法とは異なり, 有機炭素を直接, 元菜分析計 (Perkin Elmer ModeI 250）で測定する手法である。しかしながらこの方法は 有機物量の多いオイルシェール（3～24\%の有機炭素量） に対してはよい精度を持つとされるが, 有機炭素量の小 さい試料についての検討はなされていない。

松林他 (1977) は Perkin Elmer Model 250 を用 いて, 泥質岩試料を温度 $460^{\circ} \mathrm{C}$ で 11 分間燃焼させ全有機 炭素量を測定し, 従来の塩酸処理を併用する方法と比較 して同等の值が得られることを報告している。また，同
じ $460^{\circ} \mathrm{C}$ の温度条件下で炭酸カルシウムについても実 験を行い, その結果として無機炭素分解量注1) $0.02 \%$ の 值を得ている。これらの事実は，試料を低温で分解・燃 焼させる分析方法が，迅速な有機炭素量の測定に有効で あることを示唆している。しかしながら，彼らの報告で は $460^{\circ} \mathrm{C}$ みの実騟デー夕であり, 分析に最適な温度の 検討は加えていない。

一方，鈴木他（1986）は，柳本製作所侏製 $\mathrm{CHN} コ ー$ ダー・MT-3 型によって炭酸カルシウムを500 $900^{\circ} \mathrm{C} の$ 温度範囲で 5 分間燃焼し，種々の温度 $\left(50^{\circ} \mathrm{C}\right.$ 間隔)にお ける炭酸カルシウムの無機炭素分解量を詳細に検討した。 それによると， $500^{\circ} \mathrm{C}$ で $0.03 \%$ あったあのが， $600^{\circ} \mathrm{C}$ では $0.46 \%$ に増加し， $700^{\circ} \mathrm{C}$ では理論炭素量注2)である

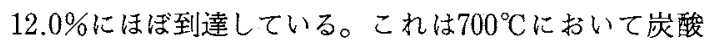
カルシウムのほとんどすべてが熱分解して, 二酸化炭素 と酸化カルシゥムに变化したことを示している。

\section{3. 試料と分析法}

\section{1 試 料}

本論では，有機炭素分析装置（CHN コーダー）の試 料加熱温度之加熱時間を変えた時の炭素分解量を調べ, 試料中の有機炭素が選択的に検出できる最適条件につい て検討を行った。岸酸塩鉱物の温度に対主る安定性を検 討するために，炭酸カルシウム（カルサイト）：Merck 社製超高純度試薬（Suprapur）扔よびドロマイト：坑 井試料（中国産）を用いた。ドロマイト試料については $\mathrm{X}$ 線分析と化学組成分析を行い, 高純度のドロマイト であることを確認して夷験に供した。

有機物の燃烇率を検討する実験には，新潟県加茂市宮 寄上付近で採取した寺泊層泥岩の地表試料（全有機炭素 量は $2.05 \%$ ，有機物の熟成度はビトリナイト反射率で 0.4\%) および北海道天北産の猿払石炭（全有機炭素量 は $62.6 \%$ ，ビトリナイト反射率は $0.37 〜 0.43 \%$ ）を用い た。なお，寺泊層泥岩は塩酸処理を施し，炭酸塩鉱物を 除去したものを用いた。

\section{2 分析法}

有機炭素分析装置には柳本製作所(侏) CHN コーダー・ MT-5 型を使用した。本装置の加熱時間は 5 分に設定さ

注 1) 炭素分解量とは, 試料が加熱により分解したときに, 6 との試料の重量に対して分解された炭素の重量パーセン トを表わす。

なお，本論の奏験では，試料中の炭素は二酸化炭素に 変換されて検出される。

注 2) 理論炭素量之は, 例えば炭酸カルシウム $\left(\mathrm{CaCO}_{3}\right.$, 分子 量100.09）の場合，その中に含まれる炭素（C，原子量 12.01) の割合を示し，完全に熱分解されたときに得ら れる無機炭素量に等しい。 
れているが，10分，15分での測定が可能なように改造を 施した。

加熱温度については試料が実際に燃焼管内で位置する 場所での温度を横河電気侏製2455型ブジタル温度計を用 いて測定し，補正した。

MT-5 型はMT-3 型の改良機種であり, 装置の任様と 測定原理については鈴木ら(1986).の報告を参照されたい。 実験では試料（10mg～100mg）の，加熱温度（400 ${ }^{\circ} \mathrm{C} \sim 850^{\circ} \mathrm{C}$ ) と加熱時間 (5 分, 10 分, 15 分) を変化さ せて炭素分解量を測定した。炭素定量用の標準試薬とし てはアセトアニリドを用いた。

\section{4. 結果と考察}

試料が害際に加熱される際の温度は，ヒータ一の制御 方式, 熱容量, 熱電対の位置, 実験室の室温などにより 設定温度と異なることが予想された。また，データの客 観性を考慮すると正確な加熱温度を計測する必要がある ため, 実験に先立ち加熱温度の正確な計測を行った。温 度の测定にはデジタル温度計を用い, 試料の燃焼位置で の温度を実測した。その結果を表 1 に示した。結果は設 定温度に対して実測温度が $20^{\circ} \mathrm{Cから} 26^{\circ} \mathrm{C}$ 高く出ており, 設定温度が高くなるに従い温度差む徐々に大きくなる傾 向がみられた。このことは，分析に際して装置の加熱温 度を正確に補正しておく必要凤あることを示している。 なお，これまでの報告では加熱温度の実測は行われてい ない。

4.1 炭酸塩鉱物（カルサイト，ドロマイト）の無機 炭素分解量

図 1 に炭酸カルシウム（カルサイト）を加熱時間15分 で熱分解した時に得られる無機炭素分解量と加熱温度之 の関係を示した。なお，加熱温度は実測值をとってある。

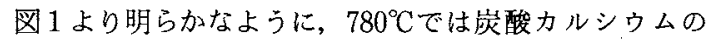

表 1 元素分析装置の設定燃焼温度と実测温度

\begin{tabular}{c|c|c}
\hline $\begin{array}{c}\text { 設定温度 } \\
\left({ }^{\circ} \mathrm{C}\right)\end{array}$ & $\begin{array}{c}\text { 実湘温度 } \\
\left({ }^{\circ} \mathrm{C}\right)\end{array}$ & $\begin{array}{c}\text { 温度差 } \\
\left({ }^{\circ} \mathrm{C}\right)\end{array}$ \\
\hline 478 & 498 & 20 \\
480 & 500 & 20 \\
498 & 520 & 22 \\
519 & 540 & 21 \\
538 & 561 & 23 \\
557 & 580 & 23 \\
575 & 599 & 24 \\
626 & 652 & 26 \\
750 & 776 & 26 \\
825 & 850 & 25 \\
\hline
\end{tabular}

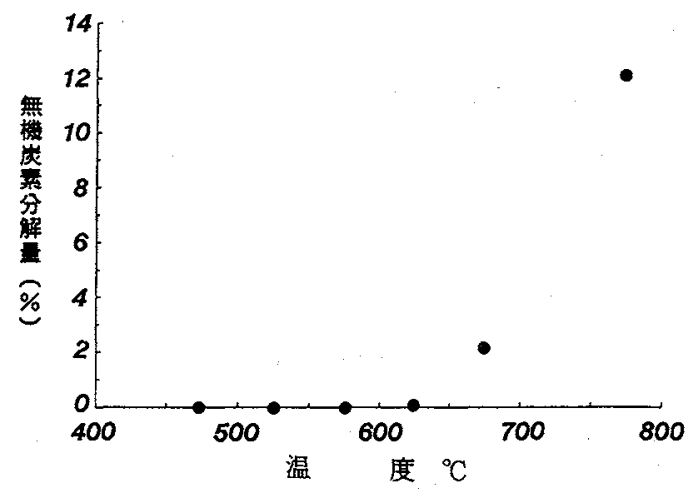

図 1 炭酸カルシウムの加熱温度と無機炭素分 解量の関係

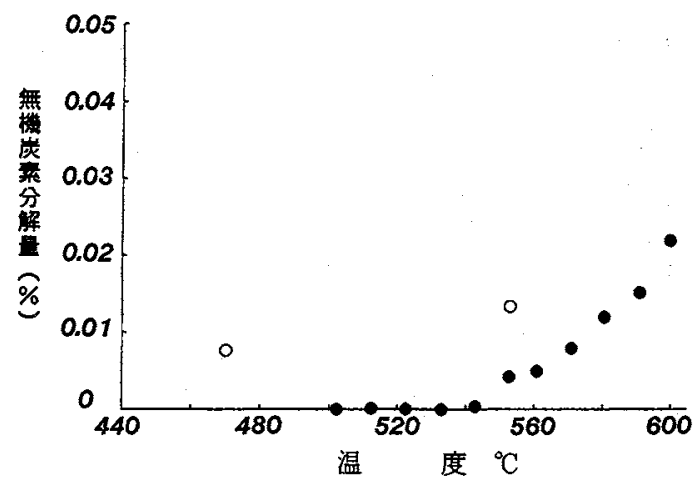

図 2 炭酸カルシウムの加熱温度と無機炭素分 解量の関係 $(O$ :一級試薬, ○: 超高純 度試薬)

分解量は理論炭素量である $12.0 \%$ を示すが， $600^{\circ} \mathrm{C}$ 以下 の温度域ではカルサイトが分解されにくい傾向を示して いる。

$600^{\circ} \mathrm{C}$ 以下での温度域に対して無機炭素分解量をさら に詳細に検討した結果を図 2 に示した。炭酸カルシウム の無機炭素分解量は, $530^{\circ} \mathrm{C}$ 以下の温度域では測定限界 以下にあり，ほとんど熱分解が起こっていない。 $550^{\circ} \mathrm{C}$ に温度が上がると無機炭素量は $0.004 \% ， 600^{\circ} \mathrm{C}$ では 0.02\%になるが，その值はきわめて小さい。試薬一級 (関東化学桻製) の炭酸カルシムについて, 同様の実験 を $470^{\circ} \mathrm{C}$ と $560^{\circ} \mathrm{C} の 2$ 点で実施した結果, 超高純度試薬に 比較して高い無機炭素分解量を示した（図2)。このこ とは一級の試薬には微量の不純物が含まれており，これ らの不純物が熱分解したことによる影響と考元られる。 先に述べた松林ら（1977）, 鈴木ら（1986）の報告では, 使用した炭酸カルシウム試薬は一級または特級であり, そのため $460^{\circ} \mathrm{C}$ で $0.02 \%, 550^{\circ} \mathrm{C}$ で $0.03 \%$ という高い 
無機炭素分解量を示したと考えられる。

一方，地質試料の炭酸塩鉱物としては，カルサイト （炭酸カルシウム）の他にドロマイトあ含まれることが 多く，ドロマイトについても炭酸カルシゥムと同様の実 験を行った。ドロマイトは $\mathrm{CaMg}\left(\mathrm{CO}_{3}\right)_{2}$ の化学式で表 され，その理論炭素量は $13.03 \%$ ある。

図 3 に示されるようにドロマイトは加熱温度 $800^{\circ} \mathrm{C}$, 加熱時間 5 分でほぼ全部が分解し，炭酸カルシウム之同 様に温度が低くなると急激に無機炭素分解量が減少する 傾向がある。そこで, $450{ }^{\circ} \mathrm{C}$ から $550^{\circ} \mathrm{C}$ の温度範囲にお いてドロマイトの熱分解により検出される無機炭素分解 量をさらに検討した。なお， $600^{\circ} \mathrm{C}$ 以下では炭素分解量 が 0.1\% 0.2\%の值を示したが（四 3），これは天然試 料であるドロマイト中の不純物が分析值に影響を与えた あのと考えられる。この不純物の同定に関しては未解決 であるが，有機物の可能性を無視することはできない。 後述するが，有機物は 15 分間の加熱により $500^{\circ} \mathrm{C}$ では $80 \% ， 550^{\circ} \mathrm{C}$ では $90 \%$ 以上が燃焼して試料から除去さ れる。一方，ドロマイトの熱分解反応は温度に依存する

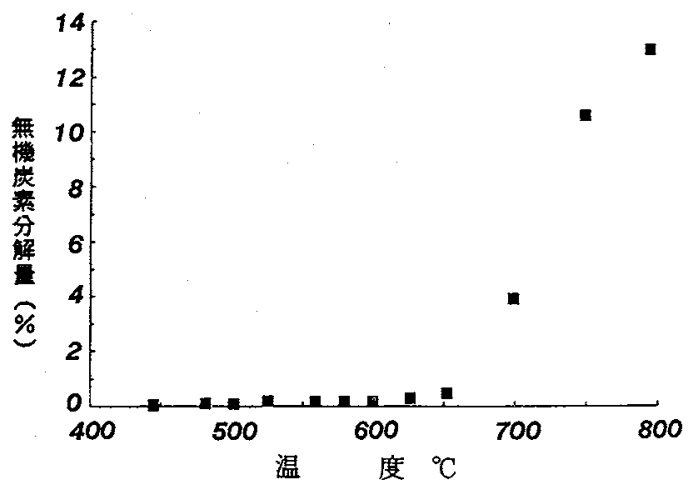

図 3 ドロマイトの加熱温度とむき炭素分解量の関係

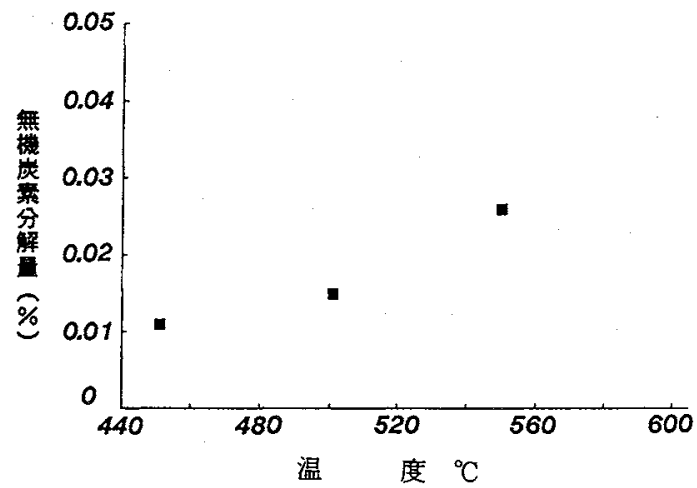

図 4 前処理済みのドロマイトの加熱温度と無機炭 素分解量の関係
反応であり，ある温度における熱分解率は常に一定であ ると考えることができる。ドロマイト自身は $600^{\circ} \mathrm{C}$ 以下 の加熱温度ではきわめて安定であるので（図 3），ド口 マイトからの分解炭素を正確に測定するために，試料を あらかじめ加熱処理 $\left(450^{\circ} \mathrm{C} \sim 550^{\circ} \mathrm{C} ， 30\right.$ 分) し，有機物 の影響を除去して，実験に供した。なお，この前処理に よる試料の重量減少はほとんどなかった。

図 4 にこの前処理を施した試料を $450^{\circ} \mathrm{C}, 500^{\circ} \mathrm{C}$, $550^{\circ} \mathrm{C}$ の加熱温度で 15 分間加熱した際の無機炭素分解量 をプロットした。炭酸カルシウムに比較してドロマイト は低温で分解されやすいが，分解によって検出される無 機炭素量は $550^{\circ} \mathrm{C}$ でも $0.026 \%$ というきわわて低い值を 示した。

従って，カルサイトあるいはドロマイトから成るほと んど純粋な炭酸塩岩中の有機炭素量を加熱温度 $550^{\circ} \mathrm{C}$ て 測定した場合，炭酸塩鉱物が有機炭素量值に与える影響 は試料の重量に対して $0.03 \%$ 末満に過ぎない。

\section{2 検量線の検討}

4.1 では 100 200mg の炭酸カルシウム及びドロマイ 卜を用いて実験を行い，最小值約 $0.002 \%$ までの無機炭 素分解量を測定した。これは炭素量にして $2 \mu \mathrm{g} \sim 4 \mu \mathrm{g}$ に相当する。そこで, MT-5 型 CHN コーダーのこのよ うな微量の炭素重量に対する検出限界について娭討した。 試薬はアセトアニリド $\left(\mathrm{C}_{8} \mathrm{H}_{9} \mathrm{ON}\right.$ ，炭素量 $\left.71.09 \%\right)$ を

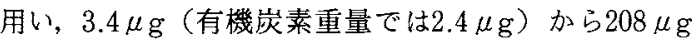
（同148 $\mu \mathrm{g}$ ）の範囲内で10点を分析した。なお，測定は 加熱温度 $850^{\circ} \mathrm{C}$, 加熱時間 5 分の従来の方法で行った。

四5にアセトアニリドの重量と分析值である有機炭素 量のカウント数の関係を示した。眓より明らかなように, 分析デー夕はきわ蛙てよい直線性を示すことから，微量 な炭素量約 2 4 $\mu \mathrm{g}$ の検出が十分可能であると判断さ れた。

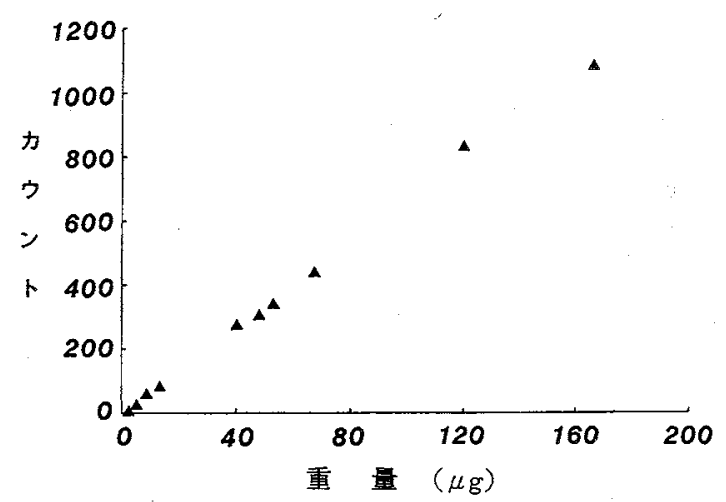

図 5 有機炭素定量用アセトアニリドの検量線 


\section{3 泥質岩及び石炭試料の有機炭素分解量}

炭酸塩鉱物を含む地質試料の有機炭素量を測定するに は，試料中の有機物を高温で燃焼させ，すべて二酸化炭 素に変換する必要がある。一方，炭酸塩鉱物の分解をで きるだけ抑えることを考えるなら，加熱温度は可能な限 り低くしなけれ代ならない。そこで，泥質岩及び石炭試 料を用いて加熱温度と時間を变化させたときの有機炭素 分解量の変化について検討した。

図6 に加熱時間 5 分，10分，及び15分における寺泊層 泥岩の分析結果を示した。試料はあらかじめ塩酸処理を 施し炭酸塩鉱物を除去したものを用いた。同じ加熱時間 であれば加熱温度が低くなるに従い検出される有機炭素 分解量は小さくなり， $600^{\circ} \mathrm{C}$ 以下では急減する。また， 同じ加熱温度では加熱時間が長くなるに伴い，収率は大 きくなる。寺泊層試料の全有機炭素量を $2.05 \%$ （加熱 温度 $850^{\circ} \mathrm{C}$, 加熱時間 5 分の従来の燃焼方法に上る) と

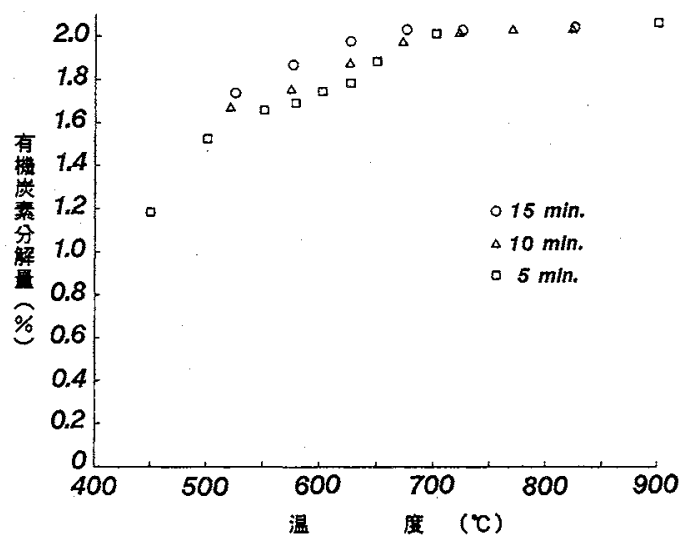

図 6 寺泊層泥岩（塩酸処理済み）の加熱温度 之有機炭素分解量の関係 ( $\square$ : 加熱時間 5 分, $\triangle: 10$ 分, $\bigcirc: 15$ 分)

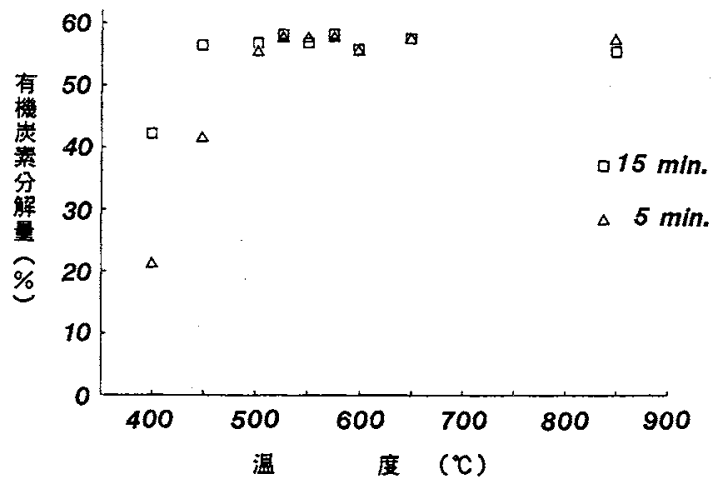

図 7 猿払石炭の加熱温度之有機炭素分解量の 関係 $(\triangle:$ 加熱時間 5 分， $\square: 15$ 分）
して，全有機炭素量の $90 \%$ 以上すなおち試料の有機 炭素分解量にして $1.8 \%$ 以上が検出できる温度条件は， 5 分の加熱時間では $630^{\circ} \mathrm{C}, 10$ 分では $600^{\circ} \mathrm{C}, 15$ 分では $540^{\circ} \mathrm{C}$ とる。

図 7 に加熱時間 5 分と15分における猿払石炭の分析結 果を示した。 $850^{\circ} \mathrm{C} \sim 500^{\circ} \mathrm{C}$ までは加熱時間による有機 炭素分解量の差は見られないが，500 $\mathrm{C}$ 以下では加熱時 間が長いほじ有機炭素分解量は大きくなる。加熱時間 5 分では $500^{\circ} \mathrm{C}$ で, 15 分で壮 $450^{\circ} \mathrm{C}$ でほぼ全ての有機炭素 が検出される。この結果を図 6 と比較すると，寺泊層泥 岩の場合, 有機炭素分解量が $600^{\circ} \mathrm{C}$ から徐々に減少する のに対して，石炭では同様な傾向は認められない。これ は，泥岩の場合，多量に含まれる粘土鉱物が，有機物の 周囲を取り囲み熱分解生成物を吸着するなどの影響を与 えたためと考えられる。

これら泥岩と石炭の分析結果加ら, 加熱温度 $550^{\circ} \mathrm{C}$, 加熱時間 15 分の条件下で試料中の $90 \%$ 以上の有機炭素 が測定可能であることが判明した。なお，前述したよう に同条件下では無機炭素が及诂す影響は試料重量に対し て最大 $0.03 \%$ でる。従って, 加熱温度 $550^{\circ} \mathrm{C}$, 加熱時 間15分の条件では，有機炭素の $90 \%$ 以上を検出し，無 機炭素の影響は試料重量の $0.03 \%$ 未満となり，炭酸塩 岩の有機炭素分析に十分適用できる。

\section{4 炭酸壏岩試料の分析}

実際の㞸酸塩岩を加熱温度 $550^{\circ} \mathrm{C}$ ，加熱時間 15 分の条 件で分析した結果と，従来法（塩酸処理法）による分析 の結果を表 2 に示した。試料は高知県の鳥の巣石死岩 (ジュラ紀)，米国デラウェア盆地のボーンスプリング石 灰岩 (二畳紀)，岩手県の川内層石灰岩（シルル紀）で ある。

川内層石灰岩は塩酸观理法と低温燃燒法の分析値が之 あによい一致を示したが，鳥の巣石灰岩では低温燃焼法 の方が，また，ボーンスプリング石灰岩では塩酸処理法

表 2 酸処理法之低温燃焼法による石灰岩試料 の有機炭素量分析結果

\begin{tabular}{|c|c|c|}
\hline & 酸处理法 $(\%)$ & 低温燃焼法 (\%) \\
\hline 鳥の巣石灰岩 & $\begin{array}{l}0.096 \\
0.096 \\
0.091\end{array}$ & $\begin{array}{l}0.159 \\
0.158\end{array}$ \\
\hline 川内層石灰岩 & $\begin{array}{l}0.077 \\
0.077 \\
0.098 \\
\end{array}$ & $\begin{array}{l}0.074 \\
0.075\end{array}$ \\
\hline $\begin{array}{l}\text { ボーンスプリング層 } \\
\text { 石 灰岩 }\end{array}$ & $\begin{array}{l}0.216 \\
0.217\end{array}$ & $\begin{array}{l}0.140 \\
0.139\end{array}$ \\
\hline
\end{tabular}


の方が高い值を示した。このような分析方法によるデー 夕の偏差の理由としては塩酸処理過程に招㚈る重量口ス があげられる。石灰岩は構成物質の大部分が炭酸塩鉣物 であり，有機物量が元来小さいので，塩酸処理後に回収 される残笪量はきわめて少量である。そのため，酸処理 過程に极ける回収口スは原岩の有機物量を実際上りあ減 じることになる。また，塩酸処理により有機物の一部が 加水分解を受けて可溶化し，その結果，分析值が小さく なる可能性む考元られる。一方, 本研究では十分量の $2 \mathrm{~N}$ 塩酸を用いて, 約 $50^{\circ} \mathrm{C}$ で 1 時間反応させ, 目視で 泡の生成が認められない時点を反応終了の基準にしてい るが，炭酸塩鉱物の分解を完全には確認していない。仮 に，末反応の炭酸塩鉱物が微量でも存在するならば，有 機炭素量は過大に評価されることになる

さらに，低温燃焼法自身の残された課題としては，シ デライト $\left(\mathrm{FeCO}_{3}\right)$ の影響があげられる。シデライト は $550^{\circ} \mathrm{C}$ の温度では $2 \sim 3 \%$ の無機炭素分解量を示すた め(山田，未発表），シデライトを多量に含む試料では 有機炭素分析值が大きく影響を受ける。また，古い地 質時代試料中には分解されにくい有機物が存在し，低 温燃焼法では分析值が低くでる可能性あある。これら の問題点については今後詳細に検討しなくてはならな い。

このように，塩酸処理法，低温然焼法とうに，現時点 ではまだ検討課題が残されているが，低温燃焼法は塩酸 前処理という煩雑な作業が不要な上，少量（数 $10 \mathrm{mg}$ 加ら100mg）の原岩の粉末試料加ら直接全有機炭素量 を求めることができるなど大きな利点を有している。炭 酸塩岩試料の場合は元来有機物量がきわめて小さいにも 関わらず，低温燃焼法と塩酸処理法とではほぼ同等の分 析値が得られた（表2）。これは，低温燃焼法が泥質岩 試料にす十分に応用できることを示唆している。すなわ ち，泥質岩試料は炭酸塩岩試料と比べて有機物量は大き く，また炭酸塩鉱物は少ないことから，低温燃焼法と 塩酸処理法との分析值の差は炭酸塩岩試料に比べて小さ いと予想される。

低温燃焼法は多数の試料をルーチン的に分析してスク リーニングする場合に特に有効である。その結果をもと に，精查の必要な試料を選択して塩酸処理法を適用する ならば，作業時間を大幅に短縮することが可能となる。 低温燃焼法に残された課題としては，前述の通り，シデ ライトの熱分解による無機炭素分解量を検討することが あげられる。また，現世堆積物試料や泥質堆積岩試料に ついてむ低温燃捳法と従来の塩酸処理法とを比較するこ とも必要である。

\section{5. 結 論}

1）低温燃焼法（試料加熱温度 : $550^{\circ} \mathrm{C}$ ，加熱時間 : 15 分）では原岩の粉末試料から直接，全有機炭素量を 求めることが可能である。この条件下で分析を行っ たとき，試料中に存在する有機物の $90 \%$ 以上が検出 される。また，炭酸塩鉱物の影響は試料重量に対し て $0.03 \%$ 末満である。

2）低温燃焼法を用いた場合，分析に要する時間，作 業量を大幅に短縮することが可能である。また，分 析に必要な試料の量は $100 \mathrm{mg}$ 程度である。

\section{謝 辞}

本論文をまとめるに当たり，石油公団石油開発技術セ ンタ一地質・地化学研究室長佐藤俊二博士および松林英 樹調查役には粗稿を読んで頂き，有益な゙御助言を賜った。 ここに記して厚く感謝の意を表する。

\section{参 考 文 献}

DEAN, W. E., 1974: Determination of carbonate and organic matter in calcareous sediments and sedimentary rocks by loss on ignition: comparison with other methods. Jour. Sed. Petrology, 44, 242-248.

HeisTAND, R. N. and HUMPHRIES, H. B., 1976: Direct determination of organic carbon in oil shale. Analytical Chemistry, 48 (8), 11921194.

HUNT, J. M., 1961: Distribution of hydrocarbons in sedimetary rocks. Geochim. Cosmochim. Acta, 22, 37-49.

HunT, J. M., 1972: Distribution of carbon in the crust of the earth, AAPG. Bull., 56, 22732277.

KROM, M. D. and BERNER, R. A., 1983: A rapid method for the determination of organic and carbonate carbon in geological samples. Jour. Sed. Petrology, 53, 660-663.

松林英樹 - 工藤修治 - 森島 宏 - 佐藤俊二 ・浅川 忠, 1977: 有機炭素の迅速測定法の開発. 石油開発技術セ ンター年報（昭和 51 年度）, p. 6.

佐藤俊二・佐々木清隆・田口一雄, 1972：秋田・新潟地 域油田新第三系の有機炭素量之抽出性有機物量一燃焼 法による有機炭素分析の検討に言及して一。地質雑, 78(12), 643-651

鈴木徳行 - 山本順三・村中英寿 · 高安克己 - 山内靖喜 · 
大西郁夫・徳岡隆夫・島田昱郎・三梨 昂, 1986: ヤ ナコ CHN コーダー（MT-3 型）による地質試料の分 析 1. 一低温燃焼法, 酸処理燃焼法による堆積物有機 炭素の定量とパソコンとのオンライン化一。島根大学 地質学研究報告, 5, 19-34。
田口一雄, 1982: 炭酸塩石油根源岩に関する研究(1)炭酸 塩堆積物中の有機物の特質について。石技誌，47（1）, 62-72.

田口一雄, 1982: 炭酸塩石油根源岩に関する研究(2)根源 岩としての石油地化学的問題. 石技誌, 47 (2), 85-92. 